\title{
The coexistence of endemic species of Astyanax (Teleostei: Characidae) is propitiated by ecomorphological and trophic variations
}

\author{
Fabio Teruo Mise ${ }^{1,3}$, Rosemara Fugi ${ }^{1,2}$, João Paulo Alves Pagotto ${ }^{I}$ \& Erivelto Goulart ${ }^{1,2}$ \\ ${ }^{1}$ Programa de Pós-graduação em Ecologia de Ambientes Aquáticos Continentais - PEA, \\ Universidade Estadual de Maringá - UEM, CEP 87020-900, Maringá, PR, Brazil \\ ${ }^{2}$ Núcleo de Pesquisas em Limnologia, Ictiologia e Aquicultura - Nupélia, \\ Universidade Estadual de Maringá - UEM, CEP 87020-900, Maringá, PR, Brazil \\ ${ }^{3}$ Corresponding author: Fabio Teruo Mise, e-mail:fabio_mise@hotmail.com
}

MISE, F.T., FUGI, R., PAGOTTO, J.P.A. \& GOULART, E. The coexistence of endemic species of Astyanax (Teleostei: Characidae) is propitiated by ecomorphological and trophic variations. Biota Neotrop. 13(3): http://www.biotaneotropica.org.br/v13n3/en/abstract?article+bn00513032013

\begin{abstract}
The aim of the present study was to evaluate factors that may favor the coexistence of three endemic species of Astyanax (Astyanax bifasciatus, Astyanax minor and Astyanax gymnodontus ) in Segredo Reservoir (Iguaçu River, Paraná State, Brazil), and to test the hypothesis that these species share food resources, being the dietary variations related to morphological characteristics. Fish were collected at three samplings sites in 1993 and 1994, during the first year after the filling phase of the reservoir. The diet was assessed using stomach content analysis and ecomorphology by ecomorphological indices. Diet and ecomorphology data were ordinated by multivariate techniques (DCA and PCA, respectively), aiming to characterize trophic guilds and identify ecomorphological patterns. A MRPP was performed to check differences between diet and morphology of species. Trophic and ecomorphological patterns were recorded among the Astyanax species, and significant differences were found for both aspects. In this way, our results corroborate the presupposed hypothesis. Therefore, the trophic and ecomorphological segregation between Astyanax species from Segredo Reservoir can contribute to reduce the competition, favoring thus their coexistence.
\end{abstract}

Keywords: fish, resource partitioning, ecomorphological divergence, Iguaçu River, Segredo reservoir.

MISE, F.T., FUGI, R., PAGOTTO, J.P.A. \& GOULART, E. A coexistência de espécies endêmicas de Astyanax (Teleostei: Characidae) é propiciada por variações tróficas e ecomorfológicas. Biota Neotrop. 13(3): http:// www.biotaneotropica.org.br/v13n3/pt/abstract?article+bn00513032013

Resumo: O objetivo deste estudo foi avaliar os fatores que favorecem a coexistência de três espécies endêmicas de Astyanax (Astyanax bifasciatus, Astyanax minor e Astyanax gymnodontus) no reservatório de Segredo (rio Iguaçu, Paraná, Brasil), e testar a hipótese de que as três espécies partilham os recursos alimentares, sendo que as variações na dieta estão relacionadas às características morfológicas das espécies. Os peixes foram coletados em três estações de amostragem no primeiro ano após o fechamento da barragem, nos anos de 1993 e 1994. A dieta foi avaliada através da análise dos conteúdos estomacais, e a ecomorfologia através dos índices ecomorfológicos. Os dados de dieta e morfologia foram ordenados por meio de técnicas multivariadas (DCA e PCA, respectivamente), com a finalidade de caracterizar as guildas tróficas e identificar os padrões ecomorfológicos. Posteriormente, foi realizada uma MRPP para verificar a existência de diferenças quanto à alimentação e os padrões morfológicos entre as espécies. Padrões tróficos e ecomorfológicos foram registrados entre as espécies de Astyanax. Diferenças significativas foram encontradas para ambos os aspectos. Dessa forma, os resultados corroboraram a hipótese inicial, sendo a segregação trófica e ecomorfológica entre as espécies deAstyanax do reservatório de Segredo um fator que pode contribuir para diminuir a competição entre elas, favorecendo a sua coexistência no ambiente. Palavras-chave: peixe, partilha de recursos, divergência ecomorfológica, Rio Iguaçu, reservatório de Segredo. 


\section{Introduction}

Fish have a great diversity comprising more than 4,500 species described for Neotropical region (Reis et al. 2003). This large species richness contributes to a wide diversity of forms and ecological functions, establishing the importance of these organisms to the most diverse aquatic ecosystems (Lowe-McConell 1999). Thus, it is expected that the functional morphological diversity has strong effects on ecological diversity, such as in the organisms' ability to use a given resource and its reproductive success (Price et al. 2011). Therefore, studies on interspecific relationships are essential for understanding the factors responsible for the structuring and coexistence of species in the assemblages. It is important to note that the food resource partitioning is one of the main factors structuring fish assemblages (Ross 1986), which makes the knowledge of trophic interactions a valuable tool for understanding the dynamics of aquatic ecosystems.

It is assumed in ecomorphology that morphological features may be reflected in the lifestyle of organisms (Wikramanayake 1990, Wainwright 1991, Norton et al. 1995, Peres-Neto 1999), where differences in fish morphology could explain different use of trophic resources (Winemiller 1991, Pouilly et al. 2003, Casatti \& Castro 2006, Teixeira \& Bennemann 2007, Mazzoni et al. 2010, Oliveira et al. 2010, Pagotto et al. 2011). In this context, ecomorphological analyses performed with congeneric and sympatric species may present significant evolutionary results, because they minimize the influence of taxonomic relationships on the variations in body shape, and allow identifying adaptive ecomorphological divergences, solely set by natural selection (Douglas \& Mattews 1992).

Astyanax is one of the most abundant fish genera in the Neotropics, with approximately 86 species (Reis et al. 2003). This genus is among those most successful in occupying habitats newly altered by the formation of reservoirs due to its generalist and opportunistic character (Arcifa et al. 1991, Cassemiro et al. 2002, Loureiro-Crippa \& Hahn 2006). In this study, we investigate the factors that may favor the coexistence of Astyanax bifasciatus Garavello \& Sampaio, 2010, Astyanax minor Garavello \& Sampaio, 2010 and Astyanax gymnodontus (Eigenmann 1911) in Segredo Reservoir, Iguaçu River Basin, Brazil. Despite the generalist behavior may be seen as an indicative of less morphological adaptations, the coexistence of these species at high abundances in the Segredo Reservoir (Agostinho \& Gomes 1998, Baumgartner et al. 2012) suggests some mechanism that might determine the different use of the available food. Therefore the following questions were addressed: 1) Is there any resource partitioning between the Astyanax species? 2) Is there any significant ecomorphological variation between them which could explain possible patterns in resource partitioning? We tested the hypothesis that there is a resource partitioning among the three Astyanax species and that the dietary variation is related to morphological variation. Thus, the resource partitioning could help explaining the coexistence of these fish that, even being generalist, can have morphological adaptations that provide a more efficient use of some specific resources.

\section{Material and Methods}

\section{Study area}

The Segredo Reservoir ( $25^{\circ} 45^{\prime} \mathrm{S}$ and $\left.52^{\circ} 10^{\prime} \mathrm{W}\right)$ is located on the Middle Iguaçu River basin, Paraná State, Brazil (Figure 1), and is part of a series of impoundments built in this area. It was formed in 1992 , occupies $82.5 \mathrm{~km}^{2}$, with $36.6 \mathrm{~m}$ mean depth, and retention time of 47 days (Júlio Junior et al. 1998). In this region, the climatic conditions follow the general pattern described for the basin, with average temperature between $12^{\circ}$ and $16{ }^{\circ} \mathrm{C}$ in the winter (JuneSeptember) and between $20^{\circ}$ and $23{ }^{\circ} \mathrm{C}$ in the summer (DecemberMarch) (Maack 1981).

\section{Sampling}

Fish were collected during the first year after the filling phase, with monthly samplings between March 1993 and February 1994, at three sampling sites distributed along the main channel of the reservoir (Figure 1). Fishes were sampled by a set of gillnets $20 \mathrm{~m}$ long with different mesh sizes $(3,4,5,6,7,8,9,10,12$ and $14 \mathrm{~cm}$ between opposite knots - height between 1.5 and $1.7 \mathrm{~m}$ ) exposed for 24 hours, and inspected at 8:00, 16:00 and 22:00 hours. Nets were simultaneously set in open areas and at the bottom ( 7.9 m mean depth). Voucher specimens were kept intact and deposited in the Museum of Ichthyology of the Núcleo de Pesquisas em Limnologia, Ictiologia e Aquicultura (Nupélia) from the Universidade Estadual de Maringá (Astyanax bifasciatus - NUP12363; Astyanax minor- NUP2291; Astyanax gymnodontus - NUP2297, NUP2296, NUP1579), whereas for the dietary study some other specimens were measured, weighed and eviscerated in the laboratory, and the stomach removed and fixed in $4 \%$ formalin.

The three species examined in this study (Figure 2) are endemic to the Iguaçu basin (Garavello et al.1997, Baumgartner et al. 2012). These fish have been recently described by Garavello \& Sampaio (2010) (A. bifasciatus and A.minor) and redescribed by Pavanelli \& Oliveira (2009) (A. gymnodontus).

\section{Diet}

The stomach contents were analyzed under a stereomicroscope, the items identified, and their volumes were obtained by the displacement of the water column using a set of graduated cylinders (Hyslop 1980). The food items were grouped into the following categories: Terrestrial insects (Hymenoptera, Coleoptera, Lepidoptera, Hemiptera and Orthoptera), Aquatic insects (Chironomidae larvae and pupae), Crustacea (Decapoda), Other aquatic invertebrates (Copepoda, Cladocera, Ostracoda and Testacea), Algae (filamentous and unicellular), Leaves (higher terrestrial plant), Fruits/Seeds (higher terrestrial plants), and Detritus/Sediment (mixture of organic and inorganic detritus).

\section{Morphological measurements and ecomorphological indices}

The fish specimens used for morphological analysis were taken from the Nupélia's fish collection. Thirty individuals of each species were analyzed, including 31 morphological characters related to habitat occupation, swimming behavior, and trophic ecology, through linear morphological measures and areas related to the trunk, fin, head, eye, and mouth (Gatz 1979, Norton \& Brainerd 1993, Breda et al. 2005, Oliveira et al. 2010). The morphological measurements were: standard Length (SL), maximum body height (MBH), body midline height $(\mathrm{BMH})$, maximum body width $(\mathrm{MBW})$, caudal peduncle length $(\mathrm{CPdL})$, caudal peduncle height $(\mathrm{CPdH})$, caudal peduncle width $(\mathrm{CPdW})$, head length $(\mathrm{HdL})$, head height $(\mathrm{HdH})$, head width (HdW), length of snout with mouth closed (LSC), length of snout with mouth open (LSO), eye height (EH), mouth height (MH), mouth width (MW), dorsal fin length (DL), dorsal fin height (DH), caudal fin length (CL), caudal fin height (CH), anal fin length (AL), anal fin height $(\mathrm{AH})$, pectoral fin length $(\mathrm{PtL})$, pectoral fin height $(\mathrm{PtH})$, pelvic fin length $(\mathrm{PvL})$, pelvic fin height $(\mathrm{PvH})$ - and commensurate areas - Eye area (EA), dorsal fin area (DA), caudal fin area (CA), anal fin area (AA), pectoral fin area (PtA), pelvic fin area (PvA). 

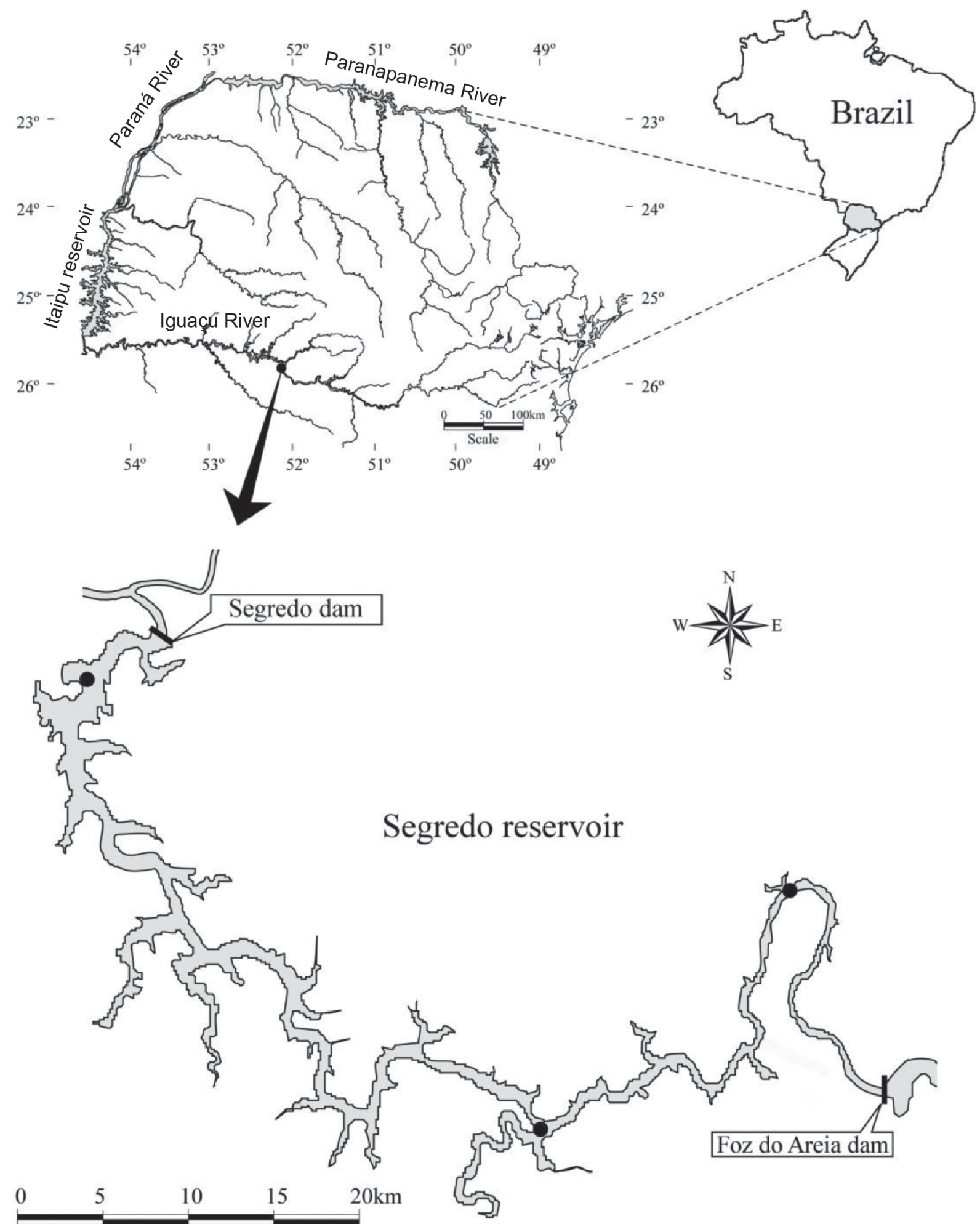

Figure 1. Location of the Segredo reservoir and the sampling stations (•).

All measures were taken from the left side of the body, using a digital caliper (accuracy of $0.01 \mathrm{~mm}$ ). Eye and fin areas were obtained by drawing the outline of the structures which were later digitized and inserted into AutoCad 2009 software for the calculation of the internal area.
From the linear measurements and areas, we calculated 26 ecomorphological indices in order to obtain proportions of the different morphological structures (Table 1). These indices are important because they eliminate the effect of individuals' size, nullifying the chance of this analysis to be dominated by this variable 


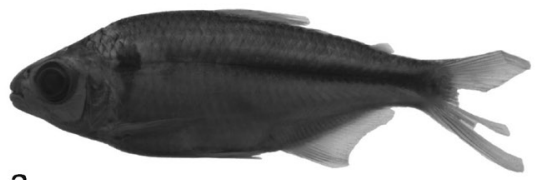

a

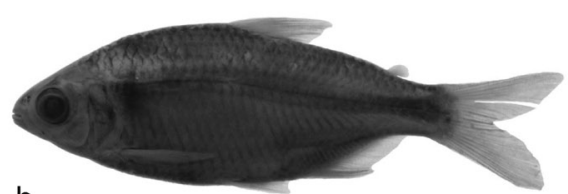

b

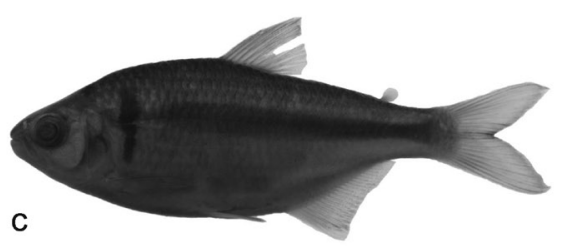

Figure 2. Specimens of Astyanax: (a) Astyanax bifasciatus ( $\mathrm{SL}=80.76 \mathrm{~mm})$; (b) Astyanax minor ( $\mathrm{SL}=73.97 \mathrm{~mm})$; (c) Astyanax gymnodontus ( $\mathrm{SL}=87.55 \mathrm{~mm})$.

Table 1. Ecomorphological indices and respective interpretation.

Relative body height - MBH/SL: Inversely related to water velocity and directly related to the ability move vertically (Gatz 1979, Watson \& Balon 1984, Winemiller 1991).

Compression index - MBH/MBW: Higher values indicate fish of structured habitats or with low water velocity (Gatz 1979, Watson \& Balon 1984).

Depression index of the ventral region - BMH/MBH: Lower values indicate benthic fish (Watson \& Balon 1984, Winemiller 1991).

Caudal peduncle compression index - CPdH/CPdW: Lower values indicate slow-swimmers (Gatz 1979, Watson \& Balon 1984).

Relative length of the caudal peduncle - CPdL/SL: Higher values indicate good-swimmers (Watson \& Balon 1984, Winemiller 1991).

Relative height of the caudal peduncle-CPdH/MBH: Lower values suggest good maneuverability (Winemiller 1991, Oliveira et al. 2010).

Relative width of the caudal peduncle - CPdW/MBW: Higher values indicate continuous swimmers or fishes with good propulsion (Winemiller 1991, Oliveira et al. 2010).

Relative head length - HdL/SL: Directly related to the food size (Watson \& Balon 1984, Winemiller 1991, Pouilly et al. 2003).

Relative head height - HdH/MBH: Directly related to the food size (Winemiller 1991).

Relative head width - HdW/MBW: Directly related to the food size (Winemiller 1991, Oliveira et al. 2010).

Relative mouth height - MH/MBH: Directly related to the food size (Gatz 1979). Lower values may be associated with a greater suction capacity (Norton \& Brainerd 1993).

Relative mouth width - MW/MBW: Directly related to the food size (Gatz 1979). Lower values may be associated with a greater suction capacity (Norton \& Brainerd 1993).

Vertical eye position - EH/HdH: Associated with the foraging position in the water column. Higher values for benthic species, lower values for nektonic species (Gatz 1979, Watson \& Balon 1984, Freire \& Agostinho 2001).

Relative area of the eye - EA/(SL) ${ }^{2}$ : Related to food detection. It can indicate the position of the species on the water column; benthic species have lower values (Gatz 1979, Wikramanayake 1990).

Index of mouth protrusion - LSO/LSC: Directly related to the ability to capture evasive and large prey (Hulsey \& García de León 2005, Cochran-Biederman \& Winemiller 2010).

Relative height of the dorsal fin - DH/MBH: High values related to the stabilization of the movements (Gosline 1971, Gatz 1979).

Relative area of the dorsal fin-DA/(SL)2: Higher values indicate greater ability for stabilization in braking and acceleration. (Breda et al. 2005).

Relative area of the caudal fin $-\mathrm{CA} /(\mathrm{SL})^{2}$ : Directly related to acceleration capacity (Breda et al. 2005).

Aspect ratio of the caudal fin $-(\mathrm{CH})^{2} / \mathrm{CA}$ : Higher values suggest caudal fin with tendency to bifurcation, typical of continuous swimmers. Lower values indicate fish with larger areas and better performance for acceleration (Breda et al. 2005).

Relative height of the anal fin - AH/MBH: Directly related to movement stabilization (Breda et al. 2005).

Relative area of the anal fin $-\mathrm{AA} /(\mathrm{SL})^{2}$ : Directly related to the maneuverability capacity and movement stabilization (Breda et al. 2005).

Aspect ratio of the anal fin - (AL) ${ }^{2} / \mathrm{AA}$ : Higher values related to greater capacity to perform rapid regression movements (Breda et al. 2005).

Relative area of the pectoral fin - PtA/(SL) ${ }^{2}$ : Directly related to movements of braking and acceleration(Gatz, 1979, Watson \& Balon

1984). In benthic fish of rapids, larger areas assist the attachment to the substrate (Casatti \& Castro 1998, Kerfoot Junior \& Schaefer 2006).

Aspect ratio of the pectoral fin - $(\mathrm{PtL})^{2} / \mathrm{PtA}$ : Directly related to swimming speed. In benthic fish of rapids, high values may favor the attachment to the substrate (Casatti \& Castro 1998).

Relative area of the pelvic fin $-\mathrm{APv} /(\mathrm{SL})^{2}$ : Higher values assist the attachment to the substrate (Kerfoot Junior \& Schaefer 2006, Casatti $\&$ Castro 1998). Lower values indicate pelagic fish (Breda et al. 2005).

Aspect ratio of the pelvic fin - (PvL) $2 / \mathrm{PvA}$ : Higher values related to capacity of braking movements (Gatz 1979). In benthic fish, high values suggest greater capacity to remain onto the substrate amidst a strong flow (Casatti \& Castro 1998).

and focusing primarily on the shape of the body and of structures (Winemiller 1991).

\section{Data analysis}

A Detrended Correspondence Analysis - DCA (Hill \& Gauch Junior 1980) was performed on the percentage values of volume of food items to investigate possible patterns in the diet of the fish species and thus characterize their respective trophic guilds. In order to check if there are significant interspecific differences between the trophic guilds, a Multi-response Permutation Procedure (MRPP) was employed. This is a non-parametric method where groups are determined a priori and a distance matrix is used to test 
the significance of differences between these groups (McCune \& Grace 2002). Thus each Astyanax species comprised a group, and the distance measure adopted was the Bray-Curtis calculated with the volume of the food items.

A Principal Component Analysis (PCA) was applied on the correlation matrix composed by the 26 ecomorphological indices aiming to identify patterns in the multivariate morphological space. The morphological data were previously log transformed to adjust the assumptions of normality and homoscedasticity. The axes retained for interpretation were chosen through the Broken-stick criterion (Jackson 1993). A Multi-Response Permutation Procedure (MRPP) was employed for checking if there are significant interspecific differences in the morphological space occupied by the three species (McCune \& Grace 2002). All statistical analyses were performed using the software PCord (McCune \& Mefford 1999).

\section{Results}

For this study, 188 stomachs were analyzed, 80 from Astyanax bifasciatus (6.1-11.5 cm standard length), 82 from Astyanax minor (6.4-9.7 cm standard length) and 26 from Astyanax gymnodontus (11.4-17.0 $\mathrm{cm}$ standard length). The diet of A. bifasciatus was basically composed of Leaves (67.6\% of the diet), followed by Terrestrial insect (21.1\%); Astyanax minor mostly consumed Detritus/ Sediment (85.7\%); and A. gymnodontus, predominantly ingested Terrestrial insect (76.6\%) (Table 2).

The first DCA axis (eigenvalue $=0.988$ ) evidenced a significant difference of the species distribution along the multivariate trophic space ( $\mathrm{p}<0.05$; Table 3 and Figure 3 ). The group with smaller scores was represented by $A$. gymnodontus, which mostly consumed Terrestrial insect, Fruit/Seed and Crustacean, being the last item found only in one stomach of this species. Astyanax minor, with higher scores preferentially consumed Detritus/Sediment, Other aquatic invertebrates, and Algae. Astyanax bifasciatus presented intermediate position in the trophic space, consuming Leaves, Terrestrial insect, and Fruit/Seed

The principal component analysis performed with the ecomorphological indices showed two significant axes $(35 \%$ of explanation; Table 4). According to the axis 1, A. gymnodontus, with negative scores presented a morphological segregation from $A$. minor, with positive scores, whereas $A$. bifasciatus presented intermediate score values (Figure 4). In this way, $A$. minor can be characterized by a greater relative body height and higher value for the aspect ratio of the caudal fin, and $A$. gymnodontus can be characterized by higher values of relative height of the head, mouth, caudal peduncle, dorsal fin, anal fin and relative width of the mouth (Table 4). Although the second axis was significant, according to the Broken-stick criterion (percentage of explained variability by PC $2=11.6 \%$ ), it did not reveal additional information about the interspecific ecomorphological patterns.

Comparing different pairs of species in relation to ecomorphological indices, the MRPP allowed verifying a significant difference for two combinations: $A$. minor $\times$ A. bifasciatus and A. minor $\times$ A. gymnodontus. No significant difference was detected between $A$. bifasciatus and A. gymnodontus (Table 5).

\section{Discussion}

The resources used by Astyanax species in this study like terrestrial insect, detritus/sediment and leaves are widely available

Table 2. Diet composition (\% volume) of Astyanax species of the Segredo Reservoir, Iguaçu River, Paraná State, Southern Brazil.

\begin{tabular}{lccc}
\hline & A. bifasciatus & A. minor & A. gymnodontus \\
\hline Leaves & 67.65 & 5.22 & - \\
Fruit/Seed & 8.41 & - & 17.66 \\
Terrestrial insect & 21.08 & - & 76.60 \\
Crustacean & - & - & 5.74 \\
Aquatic insect & 0.55 & 2.26 & - \\
Other aquatic inver- & - & 0.70 & - \\
tebrates & & & - \\
Algae & - & 6.09 & - \\
Detritus/Sediment & 2.31 & 85.73 & - \\
\hline
\end{tabular}

Table 3. Comparison between the pairs of species presented by the MRPP with the volume of food items, using the Bray-Curtis distance. T refers to statistic $t$, as a separation measure; A indicates the chance-corrected withingroup agreement; and p values indicate the significance.

\begin{tabular}{lccc}
\hline & T & A & P \\
\hline A. minor $\times$ A. bifasciatus & -76.25 & 0.29 & $<0.05$ \\
A. minor $\times$ A. gymnodontus & -53.45 & 0.27 & $<0.05$ \\
A. bifasciatus $\times$ A. gymnodontus & -23.33 & 0.12 & $<0.05$ \\
\hline
\end{tabular}


Figure 3. Ordination of the DCA applied to the volume of food items found in the stomach contents of each species of Astyanax. 
Table 4. PCA loadings. In bold, greater values, positive or negative, used for interpretation. The eigenvalues and variance of each axis are also presented.

\begin{tabular}{lrr}
\hline & PCA 1 & PCA 2 \\
\hline Relative body height & $\mathbf{0 . 7 9 4}$ & -0.339 \\
Compression índex & 0.444 & -0.370 \\
Depression índex & -0.458 & 0.297 \\
Caudal peduncle compression índex & -0.183 & -0.159 \\
Relative length of the caudal peduncle & 0.112 & 0.198 \\
Relative height of the caudal peduncle & $\mathbf{- 0 . 7 0 7}$ & 0.335 \\
Relative width of the caudal peduncle & 0.095 & 0.120 \\
Relative head length & -0.358 & -0.364 \\
Relative head height & $\mathbf{- 0 . 8 7 8}$ & -0.064 \\
Relative head width & $\mathbf{- 0 . 6 1 0}$ & -0.168 \\
Relative mouth height & $\mathbf{- 0 . 7 6 6}$ & -0.095 \\
Relative mouth width & $\mathbf{- 0 . 7 0 2}$ & -0.141 \\
Vertical eye position & -0.365 & 0.255 \\
Relative area of the eye & 0.307 & -0.476 \\
Índex of mouth protrusion & -0.054 & -0.100 \\
Relative height of the dorsal fin & $\mathbf{- 0 . 6 9 4}$ & -0.104 \\
Relative area of the dorsal fin & -0.221 & -0.528 \\
Relative area of the caudal fin & 0.305 & -0.426 \\
Aspect ratio of the caudal fin & $\mathbf{0 . 6 0 3}$ & 0.022 \\
Relative height of the anal fin & $\mathbf{- 0 . 6 0 5}$ & -0.203 \\
Relative area of the anal fin & 0.149 & -0.771 \\
Aspect ratio of the anal fin & -0.062 & 0.456 \\
Relative area of the pectoral fin & -0.246 & -0.505 \\
Aspect ratio of the pectoral fin & 0.312 & 0.225 \\
Relative area of the pelvic fin & -0.222 & -0.517 \\
Aspect ratio of the pelvic fin & 0.441 & 0.352 \\
Eigenvalue & 5.954 & 3.037 \\
Eigenvalue: Broken-stick & 3.854 & 2.854 \\
Explained variability (\%) & 22.901 & 11.679 \\
Accumulated variability (\%) & 22.901 & 34.58 \\
\hline & & \\
\hline
\end{tabular}

in large amounts during the early operation phases of reservoir and consumed by several fish species (Abelha et al. 2006, Hahn \& Fugi 2008). In this way, the opportunistic behavior of Astyanax species that exploit resources with high availability is corroborated. Even though, a trophic segregation was evident, being possible to determine trends for separating the three species in different guilds, such as: detritivore (Astyanax minor), insectivore (Astyanax gymnodontus), and herbivore (Astyanax bifasciatus).

The consumption of detritus by A. minor may be considered singular. Although Loureiro-Crippa \& Hahn (2006) also reported the consumption of detritus by this species in the Jordão Reservoir (Iguaçu River basin), the occurrence of this item is uncommon in the diet of other species of the same genus (Arcifa et al. 1991, Cassemiro et al. 2002, Luz-Agostinho et al. 2006, Borba et al. 2008). In the present study, the exploitation of the benthic zone by $A$. minor may be a process caused by the increasing of organic matter and sediment deposition on the bottom during the reservoir-filling phase. According to Hahn et al. (1997), this species consumed detritus in a large proportion in the first and second year after the dam closure in the Segredo Reservoir. However, the species changed the diet in the third year, when plants were reported as its main food items. In a trophic ecology study of the icthyofauna from the Salto Caxias Reservoir (Iguaçu River, Paraná State, Brazil), Cassemiro et al. (2005) recorded that the use of detritus by $A$. minor was higher upstream

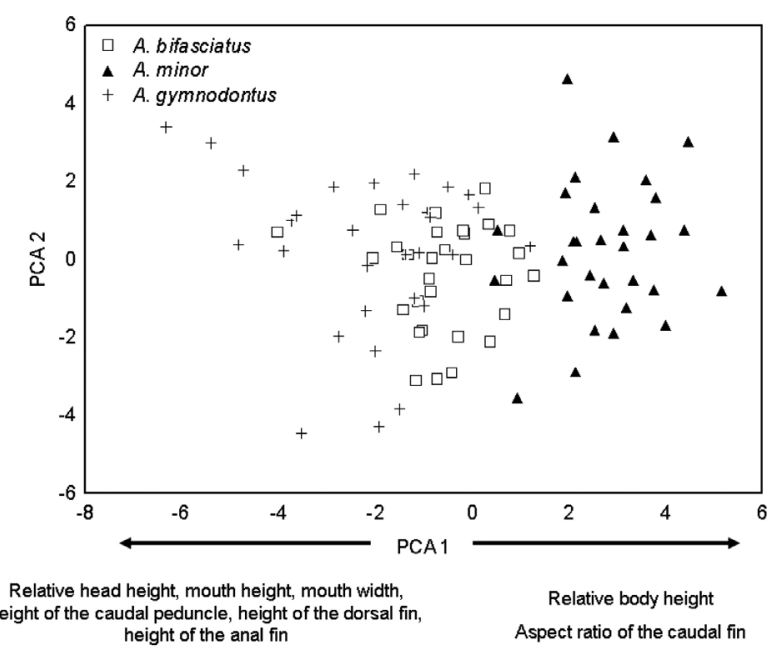

Figure 4. PCA scatter plot showing the separation of the species of Astyanax in relation to the axis 1 . The arrows indicate the indexes positively and negatively correlated with the first axis.

Table 5. Comparison between the pairs of species of Astyanax presented by MRPP on the ecomorphological indexes, using the Euclidean distance. T refers to statistic $t$, as a separation measure; A indicates the chance-corrected within-group agreement; and p values indicate the significance.

\begin{tabular}{lccc}
\hline & $\mathbf{T}$ & $\mathbf{A}$ & $\mathbf{P}$ \\
\hline A. minor $\times$ A. bifasciatus & -3.405 & 0.022 & 0.008 \\
A. minor $\times$ A. gymnodontus & -6.402 & 0.040 & $<0.05$ \\
A. bifasciatus $\times$ A. gymnodontus & -1.918 & 0.012 & 0.052 \\
\hline
\end{tabular}

the dam. On the other hand, this species fed on algae and plants in areas downstream, showing a trophic pattern similar to the pre-dam period, when it was characterized as herbivore. Therefore, there is a tendency of changing in the $A$. minor feeding strategy according to the filling phase and its location in the reservoir.

Some authors (Delariva \& Agostinho 2001, Fugi et al. 2001, Oliveira et al. 2010, Pagotto et al. 2011) suggest that specific morphological traits may be critical in determining the use of detritus among fish species, e.g. developed and protractible lips, as well as a stomach differentiated into a mechanical portion (gizzard) and another chemical portion in Prochilodus lineatus; the subterminal mouth of Steindachnerina insculpta and its shovel-shape dentary adapted to dig in the substrate; and a higher dorso-ventral flattening of Loricariidae. Thus, a better performance in the detritus exploitation by $A$. minor in comparison to the other Astyanax species can be propitiated by a relatively longer intestine (Fugi 1988), corroborating Gatz (1979) and Karachle \& Stergiou (2010) who affirm that the longer length of the gut is associated with some food items more difficult to digest, such as detritus and plants. In this case, the gut length of $A$. minor may be interpreted as an adaptive trait that can enable more efficient use of detritus in the Segredo Reservoir. Furthermore, our results indicated that $A$. minor presents greater values of relative body height, which is related to the capacity to move up- and downward in the water column, possessing thus a greater ability to move from the bottom to the surface (Gatz 1979, Watson \& Balon 1984, Winemiller 1991). This characteristic along with a higher aspect ratio of the caudal fin, which indicates more active and continuous swimmers (Breda et al. 2005), suggests that this species can use resources at several layers on the water column, mainly on the bottom, where most of its food was obtained (detritus and aquatic invertebrate). 
The insectivory reported to $A$. gymnodontus in this study is a feeding strategy similar to that observed for this species in other reservoirs from the Iguaçu River basin, where the terrestrial insect use is mainly registered in areas upstream the dam during the first two year after the impoundment (Cassemiro et al. 2005, LoureiroCrippa \& Hahn 2006). On the other hand, A. bifasciatus had its diet characterized by a higher consumption of plants. This alimentary trend was corroborated in other reservoirs from the Iguaçu River basin (Cassemiro et al. 2005, Loureiro-Crippa \& Hahn 2006). Although some changes were recorded in the diet of $A$. gymnodontus and $A$. bifasciatus over the years (Hahn et al. 1997, Cassemiro et al. 2005, Loureiro-Crippa \& Hahn 2006), in general, both species tended to exploit their feeding resources on the pelagic zone, especially allochthonous items that are drifting, such as leaves, fruits, seeds and terrestrial insects.

The highest value for the indices related to the food size (relative head height, relative mouth height and width) might have indicated an easier ingestion of relatively large food items (comparatively larger than detritus), such as terrestrial insects and leaves. At the same time, a higher swimming ability may also be determinant to explore the water surface. In this case, the ingestion of allochthonous food items may be attributed to the high values of some morphological variables (i.e. relative height of the dorsal and anal fins) related to the greater movement stabilization (Gosline 1971, Gatz 1979). A higher anal fin acts as a stabilizer rudder in swerved (Breda et al. 2005), while a large dorsal fin act as a keel, i.e. it is important in the motion orientation. These fins avoid that fish rotate on its longitudinal axis, when quick turns in the water column are made (Oliveira et al. 2010).

Therefore, our results showed that even with a high trophic plasticity that could imply in a general idea of absence of adaptation, it can be affirmed that the Astyanax species herein analyzed had morphological differences that enable the differential use of resources. Santos et al. (2011) recorded similar results in a study on the ecomorphological divergence between two Astyanax species (A. bimaculatus and A. parahybae) in a Neotropical reservoir (Funil Reservoir, southeastern Brazil). In summary, our study shows significant differences in morphology and diet between endemic Astyanax species in the Segredo reservoir on early stages of impoundment. The correlation between diet and morphology found in many ecomorphological studies (Oliveira et al. 2010, Mazzoni et al. 2010, Pagotto et al. 2011) suggests that differences in morphology can influence the feeding ecology of fish species. Following these premises, the results obtained from the studied Astyanax species may indicate a trend towards reduction in the competition for food by means of ecomorphological divergences, favoring thus the coexistence of these fish species.

\section{Acknowledgements}

We express our appreciation to Núcleo de Pesquisas em Limnologia, Ictiologia e Aquicultura (Nupélia), and Programa de Pós-graduação em Ecologia de Ambientes Aquáticos Continentais (PEA) from Universidade Estadal de Maringá (UEM) for their financial support and infrastructure; to Ichythyological Museum of Nupélia for the permission to conduct the research on their properties, and to the Coordenação de Aperfeiçoamento de Pessoal de Nível Superior (CAPES/ Ministério da Educação) for providing grants to FT Mise and JPA Pagotto. We are grateful to Luiz F. C. Tencatt for the photographs of the fish specimens; to Dra. Norma S. Hahn,Dr. Horácio F. Júlio Junior (both from UEM), and the two anonymous referees for helpful comments on the manuscript.

\section{References}

ABELHA, M.C.F., GOULART, E., KASHIWAQUI, E.A.L., \& da SILVA, M.R. 2006. Astyanax paranae Eigenmann, 1914 (Characiformes: Characidae) in the Alagados reservoir, Paraná, Brazil: diet composition and variation. Neotrop. Ichthyol. 4(3):349-356. http://dx.doi.org/10.1590/ S1679-62252006000300006

AGOSTINHO, A.A. \& GOMES, L.C. 1998. Reservatório de Segredo: bases ecológicas para o manejo. Eduem, Maringá, 387p.

ARCIFA, M.S., NORTHCOTE, T.G. \& FROEHLICH, O. 1991. Interactive ecology of two cohabiting characin fishes (Astyanax fasciatus and Astyanax bimaculatus) in an eutrophic Brazilian reservoir. J Trop Ecol. 7:257-268. http://dx.doi.org/10.1017/S0266467400005423

BAUMGARTNER, G., PAVANELLI, C.S., BAUMGARTNER, D., BIFI, A.G., DEBONA, T. \& FRANA, V.A. 2012. Peixes do baixo rio Iguaçu. Eduem, Maringá, 203p.

BORBA, C.S., FUGI, R., AGOSTINHO, A.A. \& NOVAKOWSKI, G.C. 2008. Dieta de Astyanax asuncionensis (Characiformes, Characidae), em riachos da bacia do Rio Cuiabá, Estado do Mato Grosso. Acta Sci. Biol. SC. 30(1):39-45.

BREDA, L., OLIVEIRA, E.F. \& GOULART, E. 2005. Ecomorfologia de locomoção de peixes com enfoque para espécies neotropicais. Acta Sci., Biol. SC. 27(4):371-381.

CASATTI, L. \& CASTRO, R.M. 1998. A fish community of the São Francisco River headwater riffles, southeastern Brazil. Ichthyol. Explor. Freshw, 9(3):229-242.

CASATTI, L. \& CASTRO, R.M. 2006. Testing the ecomorphological hypothesis in a headwater riffles fish assemblage of the Rio São Francisco, southeastern Brazil. Neotrop. Ichthyol. 4(2):203-214. http://dx.doi. org 1 10.1590/S1679-62252006000200006

CASSEMIRO, F.A.S., HAHN, N.S. \& FUGI, R. 2002. Avaliação da dieta de Astyanax altiparanae Garutti \& Britski, 2000 (Osteichthyes, Tetragonopterinae) antes e após a formação do reservatório de Salto Caxias, Estado do Paraná, Brasil. Acta sci., Biol. SC. 24(2):419-425.

CASEMIRO, F.A.S., HAHN, N.S., DELARIVA, R.L. 2005. Estrutura trófica da ictiofauna, ao longo do gradiente longitudinal do reservatório de Salto Caxias (rio Iguaçu, Paraná, Brasil), no terceiro ano após o represamento. Acta Sci., Biol. SC. 27(1):63-71.

COCHRAN-BIEDERMAN, J. L. \& WINEMILLER, K. O. 2010. Relationships among habitat, ecomorphology and diets of cichlids in the Bladen River, Belize. Environ. Biol. Fishes. 88(2):143-152. http://dx.doi. org/10.1007/s10641-010-9624-y

DELARIVA, R.L. \& AGOSTINHO, A.A. 2001. Relationship between morphology and diets of six neotropical loricariids. J. Fish Biol. 58:832847. http://dx.doi.org/10.1111/j.1095-8649.2001.tb00534.x

DOUGLAS, M.E. \& MATTHEWS, W.J. 1992. Does morphology predict ecology? Hypothesis testing within a freshwater stream fish assemblage. Oikos. 65:213-224. http://dx.doi.org/10.2307/3545012

FREIRE, A.G. \& AGOSTINHO, A.A. 2001. Ecomorfologia de oito espécies dominantes da ictiofauna do reservatório de Itaipu (Paraná/Brasil). Acta Limnol. Bras. 13(1):1-9.

FUGI, R. 1998. Ecologia alimentar de espécies endêmicas de lambaris do trecho médio da bacia do rio Iguaçu. Tese de doutorado, Universidade Federal de São Carlos, São Carlos. 88p.

FUGI, R., AGOSTINHO, A.A. \& HAHN, N.S. 2001. Thophic morphology of five benthic-feeding fish species of a tropical floodplain. Rev. Bras. Biol. 61(1):27-33. http://dx.doi.org/10.1590/S0034-71082001000100005

GARAVELLO, J.C., PAVANELLI, C.S. \& SUZUKI, H.I. 1997. Caracterização da ictiofauna do rio Iguaçu. In Reservatório de Segredo: bases ecológicas para o manejo (A.A. Agostinho \& L.C. Gomes, eds.). Eduem, Maringá, 387p.

GARAVELLO, J.C. \& SAMPAIO, F.A.A. 2010. Five new species of genus Astyanax Baird \& Girard, 1854 from Rio Iguaçu, Paraná, Brazil (Ostariophysi, Characiformes, Characidae). Braz. J. Biol. 70(3):847-865. PMid:21085790. http://dx.doi.org/10.1590/S1519-69842010000400016 
GATZ, A.J. 1979. Ecological morphology of freshwater stream fishes. Tulane Stud. Zoolo. Bot. 21(2):91-124.

GOSLINE, W.A. 1971. Functional Morphology and Classification of Teleostean Fishes. University Press of Hawaii, Honolulu, 208p.

HAHN, N.S. \& FUGI, R. 2008. Environmental changes, habitat modifications and feeding ecology of freshwater fish. In Feeding and digestives functions of fish. (Cyrino, J.E.P., D. P. Bureau \& B. G. Kapoor, eds.). Science Publishers New, Hampshare, p.35-65.

HAHN, N.S., FUGI, R., ALMEIDA, V.L.L., RUSSO, M.R. \& LOUREIRO, V.E. 1997. Dieta e atividade alimentar de peixes do reservatório de Segredo. In Reservatório de Segredo: bases ecológicas para manejo. (A.A. Agostinho \& Gomes, L.C., eds.). Eduem, Maringá, p.141-162.

HILL, M.O. \& GAUCH JUNIOR, H.G. 1980. Detrended correspondence analysis: an improved ordination technique. Plant Ecol. (42):47-58. http:// dx.doi.org/10.1007/BF00048870

HULSEY, C.D. \& GARCÍA DE LEÓN, F.J. 2005. Cichlid jaw mechanics: linking morphology to feeding specialization. Funct. Ecol. 19(3):487-494. http://dx.doi.org/10.1111/j.1365-2435.2005.00987.x

HYSLOP, E.J. 1980. Stomach contents analysis: a review of methods and their application. J. Fish Biol. 17:411-429. http://dx.doi. org/10.1111/j.1095-8649.1980.tb02775.x

JACKSON, D.A. 1993. Stopping rules in principal components analysis: a comparison of heuristical and statistical approaches. Ecology. 74(8):22042214. http://dx.doi.org/10.2307/1939574

JÚLIO JUNIOR, H.F., BONECKER, C.C. \& AGOSTINHO, A.A. 1998. Reservatório de Segredo e sua inserção na Bacia do Rio Iguaçu. In Reservatório de Segredo: bases ecológicas para o manejo (Agostinho, A. A, Gomes L. C., eds.). Eduem, Maringá,.p.1-17.

KARACHLE, P.K. \& STERGIOU, K.I. 2010. Intestine morphometrics of fishes: a compilation and analysis of bibliographic data. Acta Ichthyol. Piscat. 4(1):45-54. http://dx.doi.org/10.3750/AIP2010.40.1.06

KERFOOT JUNIOR, J.R. \& SCHAEFER, J.F. 2006. Ecomorphology and habitat utilization of Cottus species. Environ. Biol. Fishes. 76(1):1-13. http://dx.doi.org/10.1007/s10641-006-9000-0

LOUREIRO-CRIPPA, V.E \& HAHN, N.S. 2006. Use of food resources by the fish fauna of a small reservoir (rio Jordão, Brazil) before and shortly after its filling. Neotrop. Ichthyol. 4(3):357-362. http://dx.doi.org/10.1590/ S1679-62252006000300007

LOWE-MCCONNELL, R.H. 1999. Estudos ecológicos de comunidades de peixes tropicais. São Paulo, Edusp, 535p.

LUZ-AGOSTINHO, K.D.G., BINI, L.M., FUGI, R., AGOSTINHO, A.A. \& JÚLIO JUNIOR, H.F. 2006. Food spectrum and trophic structure of the ichthyofauna of Corumbá reservoirs, Paraná river Basin, Brazil. Neotrop. Ichthyol. 4(1):61-68. http://dx.doi.org/10.1590/S167962252006000100005

MAACK, R. 1981. Geografia física do estado do Paraná. José Olympio SA., Rio de Janeiro, 450p.

MAZZONI, R., MORAES, M., REZENDE, C.F. \& MIRANDA, J.C. 2010. Alimentação e padrões ecomorfológicos das espécies de peixes de riacho do alto Tocantins, Goiás, Brasil. Iheringia Ser. Zool. 100(2):162-168. http://dx.doi.org/10.1590/S0073-47212010000200012

McCUNE, B. \& GRACE, J.B. 2002. Analysis of ecological communities. $\mathrm{MjM}$, Oregon, 300p.

McCUNE, B. \& MEFFORD, M.J. 1999. PC-ORD: multivariate analysis of ecological data. Version 4.01. MjM, Software Design, Oregon.
NORTON, S.F. \& BRAINERD, E.L. 1993. Convergence in the feeding mode of ecomorphologically similar species in the Centrarchidae and Cichlidae. Indian J. Exp. Biol. 176:11-29.

NORTON, S.F., LUCZKOVICH, J.J. \& MOTTA, P.J. 1995. The role of ecomorphological studies in the comparative biology of fishes. Environ. Biol. Fishes. 44(12):287-304. http://dx.doi.org/10.1007/BF00005921

OLIVEIRA, E.F., GOULART, E., BREDA, L., MINTE-VERA, C.V., PAIVA, L.R.S. \& VISMARA, M.R. 2010. Ecomorphological patterns of the fish assemblage in a tropical floodplain: effects of trophic, spatial and phylogenetic structures. Neotrop. Ichthyol. 8(3):569-586.

PAGOTTO, J.P.A., GOULART , E., OLIVEIRA, E.F. \& YAMAMURA, C.B. 2011. Trophic ecomorphology of Siluriformes (Pisces, Osteichthyes) from a tropical stream. Braz. J. Biol. 71(2):469-479. PMid:21755165. http://dx.doi.org/10.1590/S1519-69842011000300017

PAVANELLI, C.S. \& OLIVEIRA, C.A.M. 2009. A redescription of Astyanax gymnodontus (Eigenmann, 1911), new combination, a polymorphic characid fish from the rio Iguaçu basin, Brazil. Neotrop. Ichthyol. 7(4):569578. http://dx.doi.org/10.1590/S1679-62252009000400003

PERES-NETO, P.R. 1999. Alguns métodos e estudos em ecomorfologia de peixes de riacho. In Ecologia de peixes de riachos. (Caramaschi, E.P., Mazzoni, R. \& Peres-Neto, P.R. eds.). Programa de Pós-Graduação em Ecologia da Universidade Federal do Rio de Janeiro. Oecologia Brasiliensis, Rio de Janeiro, p.209-236.

POUILLY, M., LINO, F., BRETENOUX, J.G. \& ROSALES, C. 2003. Dietary-morphological relationship in a fish assemblage of the Bolivian Amazonian floodplain. J. Fish Biol. 62:1137-1158. http://dx.doi. org/10.1046/j.1095-8649.2003.00108.x

PRICE, S.A., HOLZMAN, R., NEAR, T.J. \& WAINWRIGHT, P.C. 2011. Coral reefs promote the evolution of morphological diversity and ecological novelty in labrid fishes. Ecol. Lett. 14:462-469. PMid:21385297. http:/ dx.doi.org/10.1111/j.1461-0248.2011.01607.x

REIS, R., KULLANDER. S.O. \& FERRARIS JUNIOR, C.J. 2003. Check list of the freshwater fishes of South and Central America. Edipucrs, Porto Alegre, 729p.

ROSS, S.T. 1986. Resource partitioning in fish assemblages: a review of field studies. Copeia 1986(2):352-388. http://dx.doi.org/10.2307/1444996

SANTOS, F.L., CAMILO, F.L., ALBIERI, R.J. \& ARAÚJO, F.G. 2011. Morphological patterns of five fish species (four characiforms, one perciform) in relation to feeding habits in a tropical reservoir in South-eastern Brazil. J. Appl. Ichthyol. 27:1360-1364. http://dx.doi. org/10.1111/j.1439-0426.2011.01801.x

TEIXEIRA, I. \& BENNEMANN, S.T. 2007. Ecomorfologia refletindo a dieta dos peixes em um reservatório no sul do Brasil. Biota Neotrop.7(2): http:// www.biotaneotropica.org.br/v7n2/pt/abstract?article+bn00807022007 (último acesso em 17/01/2013).

WAINWRIGHT, P.C. 1991. Ecomorphology: Experimental functional anatomy for ecological problems. American Zoologist. 31:680-693.

WATSON, D.J. \& BALON, E.K. 1984. Ecomorphological analysis of fish taxocenes in rainforest streams of northern Borneo. J. Fish Biol. 25:371384. http://dx.doi.org/10.1111/j.1095-8649.1984.tb04885.x

WIKRAMANAYAKE, E.D. 1990. Ecomorphology and biogeography of a tropical stream fish assemblage: evolution of assemblage structure. Ecology. 71(5):1756-1764. http://dx.doi.org/10.2307/1937583

WINEMILLER, K.O. 1991. Ecomorphological diversification in lowland freshwater fish assemblages from five biotic regions. Ecol. Monogr. 61(4):343-365. http://dx.doi.org/10.2307/2937046 